\title{
THE IMPLEMENTATION OF INDUCTIVE APPROACH IN PRE-INTERMEDIATE STRUCTURE SUBJECT TO ENGLISH EDUCATION STUDY PROGRAM STUDENTS PGRI UNIVERSITY OF YOGYAKARTA
}

\author{
NafisahEndahati, S.Pd. M.Hum. \\ FakultasKeguruandanIlmuPendidikan, Universitas PGRI Yogyakarta \\ email: nafisah.indahatinya@gmail.com
}

\begin{abstract}
The research aims at describing the implementation of inductive approach in preintermediate structure subject to English Education Study Program students. It describes how the response of the implementation of inductive approach through communicative activities to students of English Education Study Program, Faculty of Teacher Training and Education, PGRI University of Yogyakarta.

The research was done qualitatively. It included some actions. The actions were activities of teaching and learning processes by implementing inductive approach through some communicative activities in the classroom. The subject of this research was the students of English Education Study Program, Faculty of Teacher Training and Education, PGRI University of Yogyakarta. The research data was analyzed qualitatively by using deep observation and interview. The result was represented descriptively.

The result of the research was that the implementation of inductive approach through the communicative activities can (a) train students to be familiar with the rule of discovery; (b) exploit students' greater degree of cognitive depth, (c) make the students are more active rather than being passive in the process, (d) involve students to collaboratively do problem solving, (e) involve students to get opportunity for extra language practice.
\end{abstract}

Key words: inductive approach, pre-intermediate structure, communicative activities 


\section{INTRODUCTION}

English Education Study Program, Faculty of Teacher Training and Education, PGRI University of Yogyakarta has duty to prepare students to be a professional teacher and educator who has high competency in teaching students of senior high school and junior high school students. As a teacher to be, they are taught and provided good competencies in both teaching and acquiring linguistics comprehension. To the effort of linguistic comprehension, students must take and improve their language competencies; those are speaking, listening, reading and writing. Besides that, they are also taught structure, vocabulary, pronunciation, and the others to support those four language competencies.

Providing structure, vocabulary, pronunciation and other subjects are supposed to lay the groundwork for English language system used to communicate and deliver messages. The English structure subject is the basic need for students in delivering material to students. Structure comprehension is also used for students to make good and proper sentences academically in writing research and paper. In handling good English sentence structure, students are given basic structure, pre-intermediate structure, intermediate structure and advanced structure subjects.

The subjects mentioned before are given to the students in every semester (semester 1 to semester 4). The objective of teaching English structure is mainly giving students good comprehension through English structure in order students are able to write English sentences structurally correct. There are relationships of English structure comprehension to other language competencies. The ability in English structure can improve students' ability in writing and reading. It can be said that the successful reading and writing ability are determined by the comprehension through the sentence structure.

Students of English Education Study Program have experienced in learning English since they were schooling at junior and senior high schools. They experienced learning English productively. They were encouraged to speak English without very much knowing the English sentence structure correctly and completely. As known, the approach implemented by teachers in delivering English subject in school is communicative approach. One weakness found in the implementation of communicative approach is students become less comprehension about grammar. Other reason of students' less comprehension to structure is public opinion that learning English language structure is difficult because there are many formulas need to be acquired in learning it. The opinion makes worse the students' motivation to learn structure.

While the internal factors influenced the result of structure comprehension, the external factors also play role in unsuccessful learning structure. The language teaching approach and media of teaching can also influence the unsuccessful teaching-learning 
language structure. Educators often apply approach which is not fun. This may lead to students become bored to study basic structure.

The outstanding problem faced by the students of English Education Study Program, Faculty of Teacher Training and Education is the lack motivation due to the lack of teaching approach applied in the classroom. Based on the condition, the research is focused on conducting inductive learning approach to teaching English structure to students of English Education Study Program.

\section{THEORETICAL REVIEW}

\section{A. The Definition of Structure}

Structure refers to grammar. Nunan $(154 ; 2003)$ said that grammar is generally thought to be a set of rules specifying the correct ordering of words at the sentence level. Grammar is of the language internal study (Collinge, 2005: 38). It studied form and pattern in a more in a more abstract sense. In Oxford Advanced Learners Dictionary, grammar is rules for forming words and making sentences. The grammatical units of English are words, phrase, clause and sentence (Eastwood, 1994: 8).

Grammar is the business of taking a language to pieces, to see how it works (Crystal, 2000). He also states that grammar is the system of language. People sometimes describe grammar as the system of rules or structure of a language, but in fact no language has rule. Grammar is the mental system of rules and categories that allows human to form and interpret the words and sentences of their language. Grammar adds meanings that are not easily inferable from the immediate context. The kinds of meanings realized by grammar are principally representational, that is grammar enables us to use the language to describe the worlds in terms of how, when and where things happen. Interpersonal meaning is that grammar facilitates the way we interact with other people when we need to get things done using language.

Nunan (2003: 154) states that grammar is generally thought to be a set of rules specifying the correct ordering of words at the sentence level. Grammarians distinguish between prescriptive grammar and descriptive grammar. A prescriptive grammar lays down the law, saying what is right, what is wrong. A descriptive grammar, on the other hand, sets out to describe the way that people actually use the language.

\section{B. Teaching Structure}

Grammar or structure can be introduced in number of ways, or teacher can show students grammar evidence and ask them to work out for themselves how the language is constructed. Teacher also has to provide opportunities for students to practice different grammar points, and he may use fun activities to make such practice more engaging.

There are five step procedures for teaching grammar (Widodo, 2006). The procedures incorporate the notion and practice, the consciousness-raising, the explicit and implicit knowledge, and the deductive and inductive approaches to teach English.

a. Practice 
Practice is generally accepted to facilitate accuracy and fluency. Accuracy or correct use of language can be attained through controlled and semi-controlled activities or practice. Fluency can be achieved if the students master the rules of the language taught, they are required to apply the rules of language in the form of written and spoken languages.

b. Consciousness-raising

Ellis (2002) defines that consciousness-raising as an attempt to equip learners with an understanding of a specific grammatical feature to develop declarative (describing a rule and grammar and applying it in pattern practice drills) rather than procedural (applying rule of grammar in communication) knowledge of it.

c. Explicit and implicit knowledge

Explicit knowledge is known as conscious learning, while implicit knowledge is subconscious acquisition. Explicit knowledge deals with language and the uses of language can be put. Implicit knowledge is automatic and easily accessed and provides a great contribution to building communicative skills.

d. Deductive and inductive

Dealing with teaching of grammar, deductive approach can also be called rule-driven learning. A grammar rule is explicitly presented to students and followed by practice applying the rule. Then, an inductive approach can also be called rule-discovery learning. This approach senses learners comprehend grammatical rules from the examples.

There are some principles for teaching grammar to students (Nunan, 2003: 158). The principles are mentioned as follows;

a. Integrate both inductive and deductive methods into your teaching.

In the classroom, it may bee difficult to mention which is the best between inductive and deductive. But teacher can combine the methods as needed. In this research, the researcher uses the inductive method or approach in order that learners retaining more of the language in the long term.

b. Use tasks that make clear relationship between grammatical form and communicative function.

Many grammar based courses are relatively ineffective because they teach grammar as an abstract system, present the language as isolated sentences, and fail to give learners a proper context for the grammar point. The best solution to the problem is to present the grammar in a context that makes clear relationship between grammatical form and the communicative function.

c. Focus on the development of procedural rather than declarative knowledge.

Declarative knowledge is knowing language rules. Procedural knowledge is being able to use the knowledge for communication. Students need to develop mastery the target language items, not by memorizing the rules, but by using the target items in communication context.

\section{Inductive and Deductive Approaches}


There are deductive and inductive teaching approaches usually used to teach grammar. An inductive activity is one in which students infer the rule or generalization from a set of examples (Freeman, 2002: 264). An inductive approach comes from an inductive reasoning stating that a reasoning progression proceeds from particulars to generalities (Felder \&Henriques; 1995). In short when using inductive, teacher observes a number of specific instances and from them infers a general principle or concept.

Richards \& Schmidt $(2002$, 157) mention that in inductive learning, learners are not taught grammatical or other types of rules directly but are left to discover or induce rules of a language make use of the principle of deductive learning. In grammar learning, learners understand grammatical patterns from the examples. The presentation of grammatical rules can be written or spoken. Eisenstein (cited in Long and Richards, 1987) say that the inductive approach tries to utilize the very strong reward, value of bringing order, clarity, and meaning to experiences. This approach involves learner's participating actively in their owwn instruction. It encourages the learner's mental and strategy to acquire the examples of the pattern and then they determine the rules by observing the examples.

Inductive approach comes form inductive reasoning stating that a reasoning progression proceeds from particulars (that is observations, measurements, or data) to generalities (for example rules, laws, concepts or theories) (Felder \& Henriques, 1995). In short, when we use inductive approach, we observe a number of specific instances and form them infer a general principle or concept.

\section{Communicative Activities Applied in Inductive Approach}

Communicative activities involve the implementation of some activities in which the learners have opportunities to use the target language for an authentic communication. Communicative strategies to teach English language to learners can improve students' interaction, motivation and higher order-thinking through the materials. There are some principles of communicative approach or strategies in teaching language to students (Morrow, 1981: 59-65).

a. Principle one : Know what you are doing

In doing the activities, students must know the reason why they do the activities. They must know the answers of the questions "Why am I learning this?" What am I learning to do" The purpose of every lesson is at the end of the lesson and the students can do something that they cannot do at the beginning.

b. Principle two : The whole is more than the sum of the parts

Communicative methodology not only operates with stretches of language above the sentence level, but also operates with the real language in real situation. In learning a language, students must be helped in developing skills and dealing with a set of sentences and ideas in the whole context into which the verbal communication should be processed in one time. It supposes that all elements should be connected with one another to maintain the meaning and the theme of a certain element should be determined by their positions in the whole contexts.

c. Principle three : The processes are as important as the form 
The practice of the forms of the target language can take place within the communicative framework. This third principle has the following components.

1. Information gap

Information gap must exist in the communication. Without information gap, there will be no real communication.

2. Choice

The choice is what the participants will say and how they will say the information in the communication. It means that they are free to choose what and how to say it.

3. Feedback

In communication, the participants get the feedback of what they want to get from the communication. The participants of communication communicate with others because they want to get information as feedback from doing communication.

d. Principle four: To learn it, do it.

The students learn by doing. Only by practicing communicative activities can they learn to communicate.

e. Principle five : Mistakes are not always a mistake

In communicative approach, making mistakes because students try to do something by using the forms they have never learned before should not be regarded as a mistake. However, mistakes which hamper communications are not trivial at all, and therefore should be addresses appropriately.

\section{METHODOLOGICAL FRAMEWORK}

This research method used a descriptive qualitative method. Hancock and Algozzine (2006:16) state that this method attempts to present a complete description performance of a phenomenon within its context. Hancock and Algozzine (2006:8) state that a qualitative research goal is to understand the situation under investigation primarily from the participant's and not the researcher's perspective that is called the emic or insider's perspective as opposed to etic, or outsider's perspective.

The data collected were in the form of words or pictures rather than in the form of numbers. The data included field notes, interview transcripts, and other official record. The data was descriptive narrative obtained from a series of in-depth interviews with the participants. The observation data were gained from a series of observations on learning English of students. The interview data were obtained from the participants opinion, idea, experience and feeling.

The research subjects were the students of English Education Study Program, Faculty of Teacher Training and Education, PGRI University of Yogyakarta. The students took a pre-intermediate structure class after taking basic structure. They were 27 students.

\section{RESEARCH FINDINGS AND DISCUSSION}




\section{A. The implementation of Inductive Approach Activity 1}

The research was started at the beginning of the lesson. The students were then given the explanation of the process of the teaching and learning process. They had classroom management. The classroom management was intended to have a good agreement between the lecturer and students. The classroom management was done before the process of teaching and learning activities. The agreement was written in the syllabus as the assessment for the students.

The first implementation was the activity of group discussion. The class was divided into two groups of discussion. The first group named Language, while the second group named Education. The process of the activity was mentioned as the following.

a. The class was divided into two groups.

b. First group named as Language, other named as Education.

c. Each member of Language group was given a wrong sentence. The sentence was written in a piece of paper.

d. While, the Education group was also given sentences. Each member of the Education group was given a correct sentence. The sentence was written in a piece of paper.

e. The activity was begun with each member of the Language group tried to find the correct sentence hold by member of Education group. They had to find their pairs by asking questions communicatively and orally. They might not be allowed to use written form, they had to ask questions to others orally.

f. After finding each pair, they had to discuss about the tense of the sentence. They must find the pattern of the correct sentence.

g. Every group had to find the correct tense written in the correct sentence then they must decide the pattern of the sentence.

h. Finally, the results of the discussion were re-discussed again in the classroom.

The implementation of the group discussion was done successfully. The students were able to communicate with others while they found the correct tense and pattern of the sentence. It could be shown from the interview between the researcher and one student. This is the interview quotation between the researcher and the student. $\mathrm{R}$ is researcher and $\mathrm{S}$ is student.

\begin{tabular}{|c|c|}
\hline $\mathrm{R}$ & : Bagaimanapendapatkamutentangkegiatan yang tadibarudilak \\
\hline $\mathrm{S}$ & : Bagus bu. Tadipadaawalnya \\
\hline $\mathrm{R}$ & : Kenapabingung? \\
\hline $\mathrm{S}$ & :Ya, karenaawalnyandakmendengarkanpenjelasandariibu. \\
\hline $\mathrm{R}$ & $\begin{array}{l}\text { : Oh, begitu? Makanya, besoklagi, mendengarkaninstruksinya. } \\
\text { Kamumengalamikesulitantidakpadasaatmencaripasangantadi? }\end{array}$ \\
\hline$S$ & $\begin{array}{l}\text { : Hehehe....iya } \quad \text { bu. } \quad \text { Tapisayaterusnyarisambiltanya-tanya. } \\
\text { Sampairamekantadibu? Suasanakelasnya? }\end{array}$ \\
\hline $\mathrm{R}$ & sayamalahsenangkok. \\
\hline & $\begin{array}{l}\text { Tapimenurutmukamupahamtidakdenganpoladasarkalimattadi? } \\
\text { : Mengertibuk. Tadisaya juga diskusikandenganteman yang lain kok. Ratc }\end{array}$ \\
\hline
\end{tabular}


The interview above was done after the activity of inductive approach. It can be concluded that the student was helped by the use of communicative activity implemented through inductive approach. Although they tried hard to find the pattern of themselves, they could discover the rules themselves. They found themselves involved mentally in discovering the rules of simple present tense, the past tense, and the present continuous tense. It would make meaningful and memorable.

The activity also trained the students to be actively involved in the process of learning through communicative way. They could get interaction with each other. The interaction of each member of the group happened as they had to find their pairs. If they found their pairs, then they could discuss what pattern or rule mentioned in the sentence.

The process of communicative activity as above was also encouraged students ability in communication. They were forced to ask other questions about the sentence. Asking the sentence and tense of sentence was in English language. The lecturer was given free time for students to have discussion in pairs. So they could conclude the appropriate tense of the sentence.

\section{B. The Implementation of Inductive Approach Activity 2}

This second implication was the activity of guessing game. The researcher firstly prepared a set of picture of a hero, professional, artist, singer, or other famous persons.

The guessing game was running successfully. It didn't take very long time to explain the instruction of the activity to the students because students were already familiar with the activity. First impression form the activity was that the students didn't feel bored in the learning process. Although they studied grammar forms, they felt happy with the activity done in the classroom. They also get the material clearer to understand.

Based on the interview, it can be concluded that the implementation of the inductive approach activity 2 was done successfully. It was a communicative activity that based on problem solving strategy. There was an information gap. The audience must guess the name of the famous person based on the information they got from question and answer with the speaker. While doing improving their oral competence, students should create a good interrogative sentence. The interrogative sentence was used to get much information about the one who was asked.

\section{The implementation of Inductive Approach Activity 3}

The third activity was conducted in a communicative way. The implementation of the activity was role-playing activity. The role-playing activity was implemented in pairs. The preparation to do was the picture cards written with suggestions. Before conducting the activity, the lecturer prepared some suggestion cards with pictures. The suggestions were mostly about health daily problems such as how to whiten your teeth, how maintain healthy body, etc. The material to be used in this activity was the form of should to make suggestions. 
The process of the implementation of inductive approach activity 3 was done. There were some conclusions happened based on the third implication. The first result was that the students interact more communicatively each other. She or he could speak freely. Information gap happened when the patient asked about the disease and also happened when the doctor asked about the symptoms of the disease.

The collaborative problem solving encouraged the students then got the experience to express extra language practice. The collaborative activity happened when the patient tried hard to explain the symptoms of the diseases, then the doctor also gave responses to him/her by giving suggestions.

\section{CONCLUSION}

The research has been done. It can be concluded that the implementation of inductive approach through communicative activities are useful to students. The implementation of inductive approach through communicative activities is the activity of group discussion, guessing game, and role-playing. The collaborative activities cause some beneficial condition. These can be stated as the following.

a. Learners are trained to be familiar with the rule of discovery; this would enhance learning autonomy and self-reliance.

b. Learners' greater degree of cognitive depth is exploited.

c. The learners are more active in the learning process rather than being simply passive recipients. In this activity, they will be more motivated.

d. The implementation of inductive approach through communicative activities involves learner's pattern recognition and problem solving ability in which particular learners are more interested in this challenge.

e. The problem solving activity is done collaboratively; learners get an opportunity for extra language practice.

\section{REFERENCE}

Collinge, N.E. (2005). An encyclopedia of language. New York: Taylor and Francis elibrary.

Chrystal. http://www2.vobs.at/ludescher/pdf\%20files/grammar.pdf. diunggahpadatanggal 1 Desember 2014.

Creswell, John. (2003). Research design: qualitative, quantitative, and mixed methods approaches. California: Sage Publications.

Eastwood, John. (1994). Oxford guide to english grammar. New York: Oxford University Press.

Freeman, Diane Larsen. (2000). Teaching grammar. New York: Oxford University Press. 
Hancock D. R., and Algozzine B. 2006. Doing case study research. New York: Teachers College Press.

Harmer, Jeremy.(2007). The practice of english language teaching $\left(4^{\text {th }}\right.$ ed). New York: Pearson Longman.

Holliday, A. 2002. Doing and writing qualitative research. London: SAGE Publications, Ltd.

Littlewood.W.(1981). Communicative languageteaching. Cambridge. Cambridge University Press.

Morrow, Keith and Morrow Johnson. (1981). Communication in the classroom. Application and methods for a communicative approach. England. Longman Group Ltd.

Nunan, David. (2003). Practical english language teaching. New York: Mc.Graw-Hill Companies.

Richards, Jack C \& Schmidt Richard. (2002). Longman dictionary of languageteaching and applied linguistics. United Kingdom: Person Education Limited.

Stern, H.H. (1983). Fundamental concepts of language teaching. New York: Oxford University Press.

Widodo, PujiHandoyo. (2006). Approaches and procedures of teachinggrammar.Jurnal may 2006, volume 5, number 1, pp 122-141. 